\title{
Experimental crop growing in Jordan to develop methodology for the identification of ancient crop irrigation
}

\author{
Steven Mithen, Emma Jenkins, Khalil Jamjoum, \\ Sameeh Nuimat, Stephen Nortcliff and Bill Finlayson
}

\begin{abstract}
Crop irrigation has long been recognized as having been important for the evolution of social complexity in several parts of the world. Structural evidence for water management, as in the form of wells, ditches and dams, is often difficult to interpret and may be a poor indicator of past irrigation that may have had no need for such constructions. It would be of considerable value, therefore, to be able to infer past irrigation directly from archaeo-botanical remains, and especially the type of archaeo-botanical remains that are relatively abundant in the archaeological record, such as phytoliths. Building on the pioneering work of Rosen and Wiener (1994), this paper describes a cropgrowing experiment designed to explore the impact of irrigation on the formation of phytoliths within cereals. If it can be shown that a systemic and consistent relationship exists between phytolith size, structure and the intensity of irrigation, and if various taphonomic and palaeoenvironmental processes can be controlled for, then the presence of past irrigation can feasibly be inferred from the phytoliths recovered from the archaeological record.
\end{abstract}

\section{Keywords}

Ancient irrigation; crop-growing experiments; phytoliths; Jordan.

\section{Introduction}

The experimental cultivation, harvesting and processing of cereals has played a significant role in discussions about the origin of domesticated cereals and their cultivation in later prehistoric and historic times. Such experiments have been designed to measure yields of different cereal types (e.g. van der Veen 1989; van der Veen and Palmer 1997); to measure yields when cereals are grown under different ecological conditions (e.g. Davies and 
Hillman 1988); to explore the process of domestication (e.g. Oka and Morishima 1971; Hillman and Davies 1990; Lie-Dan Lu 2002); to test the effectiveness of different harvesting methods (e.g. Anderson 1992); and to identify characteristic wear patterns that arise on stone artefacts used in harvesting or processing (e.g. Anderson 1992). In this contribution we describe an on-going experimental crop-growing programme in Jordan that is primarily designed to develop methodology for the inference of water management and more specifically crop irrigation from archaeo-botanical remains. Results concerning yields arising from different growing conditions are also presented.

\section{The challenge of inferring water management from structural remains}

The development of water management systems in the Near East has long been recognized as important for understanding socio-economic change. Although Wittfogel's (1957) 'hydraulic hypothesis' of irrigation management as the prime mover for the emergence of early states may no longer be tenable, the management requirements of irrigation systems and the potential increase in surplus that can arise from their use remain as key issues for understanding the emergence of social complexity (Scarborough 2003).

These issues are of particular interest to the Leverhulme-funded 'Water, Life \& Civilisation' (WLC) research programme at the University of Reading (www.waterlife civilisation.org). The aim of this five-year programme (2005-10) is to assess changes in the hydrological climate and its impact on human communities in the Middle East and North African area between 20,000 years ago and AD 2100 with a case study on the Jordan Valley. The project seeks to develop inter-disciplinary approaches to the past, present and future by integrating studies in meteorology, hydrology, human geography, soil science and archaeology. The development and use of water management methods, and how these relate to environmental, social and economic change, is one of its central concerns. While direct structural evidence for prehistoric water management in the Jordan Valley remains sparse, irrigation has been proposed as having played a key role in the development of the large and socially complex Chalcolithic and Bronze Age settlements (e.g. Bourke 2001; Philip 2001).

Direct archaeological evidence for water management in the Jordan Valley takes numerous forms, including wells, cisterns, field systems and irrigation ditches (Oleson 2001). Such evidence is often substantial for proto-historic and historic periods, such as the sophisticated Nabatean modifications to the siq at Petra (Bellwald and al-Huneidi 2003) or the Roman/Byzantine reservoir, aqueduct and field system in Wadi Faynan (Barker 2000). Structural evidence for water management is both more elusive and more difficult to interpret for the prehistoric periods when it is likely that water management, including the irrigation of cereals, began.

The earliest known evidence of water management in the Jordan Valley is the Pottery Neolithic well at Sha'ar Hagolan, Israel (Garfinkel et al. 2006), dated to 6400-6200 BC, although pre-Pottery Neolithic B wells dating to c. $8000 \mathrm{BC}$ and to $c .7000 \mathrm{BC}$ are known from, respectively, Cyprus (Peltenburg et al. 2000) and the coast of Israel at 'Atlit Yam (Galili et al. 2002). Garfinkel et al. (2006) believe that the Shar'ar Hagolan well had been used to provide water for human and animal consumption alone, rather than for the 
irrigation of crops. The earliest potential evidence for such water management in the Jordan Valley is the set of small terrace walls at the Neolithic site of Dhra', dated to 6000 BC by association with Jericho IX ceramics (Kuijt et al. 2007). These have been interpreted as functioning to minimize soil erosion, control water runoff during wet periods of the year, and as field systems for growing wild and domesticated plants.

Whether or not the Dhra' walls were used to provide additional water to crops remains unclear. Indeed, such uncertainty often exists even when a complex water management system is evident. At the early Bronze Age site of Jawa, for instance, there appears to have been a system of channels, dams and pools to collect and store winter flood water from the adjacent Wadi Rajil (Helms 1981, 1989). Hydrological models have been developed to estimate the size of the animal and human populations that could be sustained by such water storage (Whitehead et al. in press). But the estimates are highly dependent upon whether the stored water had also been used to irrigate surrounding fields for the growth of cereals, for which there is no direct evidence.

At other archaeological sites there may be circumstantial evidence for agricultural intensification requiring irrigation, but a complete absence of any structural evidence for water management. At the Chalcolithic site of Ghassul, for instance, Bourke (2001: 119) proposes that there had been 'elite-regulated exploitation of flood-water irrigation systems', but has no evidence for ditches, walls or dams. Such structures may not have been necessary or simply insufficiently substantial to have survived in the archaeological record. Indeed, in some cases, effective water management requires no more than minor and ephemeral adjustments to water courses, as we have observed among the Bedouin in Wadi Faynan. They use small walls of pebbles and mud to divert seasonal streams and create substantial pools of water. These are constructed in a few minutes, frequently modified and then simply washed away leaving no archaeological trace. Far more substantial evidence may have been destroyed: Philip (2001) notes that the down-cutting of wadis and the deposition of colluvium in the Jordan Valley may have removed or buried structural evidence for water management of the Early Bronze Age, for which there is direct evidence only from Tall Handaquq (Mabry et al. 1996) and Jawa (Helms 1981, 1989).

As the structural evidence for water management is difficult to interpret and may simply not exist, it would be of considerable value to have a methodology for the inference of crop irrigation directly from archaeobotanical remains, and especially from the types of remains that are relatively abundant in the archaeological record. Helbaek (1960) proposed that the size of charred flax seeds could be used to this end, while Mabry et al. (1996) suggested that the size of wheat grains from Tall Handaquq implied irrigation agriculture. Such arguments are problematic because of the impact that charring itself may have on the size of seed grains, and the numerous other factors that may also influence grain size. Charles et al. (2003) demonstrated that, when modern-day fields and crops are available for study, their weed floras can be indicative of the use of irrigation. But sufficiently well-preserved assemblages of charred plant remains from prehistoric sites for such studies are rarely - if ever - recovered from the archaeological record. Another potential indicator is the size and structure of phytoliths, these being proposed by Rosen and Weiner (1994) to be different in irrigated and un-irrigated crops. If this proposal can be validated, the relative abundance of phytoliths in the archaeological record makes this a potentially highly valuable indicator of irrigation. 


\section{Multi-celled phytoliths as indicators of ancient irrigation: the pioneering study by Rosen and Weiner (1994)}

Phytoliths are microscopic bodies of opaline silica that form within and around plant cells and are relatively durable within sediments, corroding and dissolving only when subject to alkaline conditions. They can develop as either single- or multi-celled forms, this possibly being dependent upon the amount of silica uptake by the plant which, in turn, reflects water provision (either from irrigation or rainfall), the degree of evapo-transpiration and soil chemistry. Rosen and Weiner (1994) explored the relationship between the production of multi-celled phytoliths and the use of irrigation for emmer wheat and bread wheat in Near Eastern environmental conditions.

They undertook a small-scale experiment, growing one plot of emmer wheat in irrigated and another in un-irrigated conditions at the Gilat Agricultural Research Station in the northern Negev. Both plots were subject to the same rainfall $(224 \mathrm{~mm})$ and were on identical soils, but the former also received an additional $200 \mathrm{~mm}$ of water. They found that plants from the irrigated plot had higher frequencies of multi-celled phytoliths, especially those in which more than ten cells were joined together. A similar pattern was evident from bread wheat, although the difference between irrigated and un-irrigated specimens was not as marked and failed to be statistically significant. Rosen and Weiner (1994) argued that the same result exists for barley, although they did not undertake their own experimental work. They proposed that, when dealing with archaeological samples from arid and semi-arid regions, the presence of at least 10 per cent of phytoliths having ten or more conjoined cells, or any phytoliths with 100 or more conjoined cells, provides an indication of past irrigation. They used this to infer that irrigation had been used for growing emmer wheat at two Chalcolithic sites in the northern Negev, Gilat and Shiqmim.

If this finding is correct, it is of considerable archaeological importance: by taking phytoliths from Near Eastern Neolithic, Chalcolithic and Bronze Age sites one ought to be able to map the development of irrigation both through time and across space. There are, however, four problems with the study that need to be addressed before Rosen and Weiner's proposed multi-celled phytolith indicator for irrigation can be used with confidence:

1. First is the issue of enhanced water availability coming from rainfall rather than irrigation. Rosen and Weiner downplay the significance of this by arguing that, on average, a higher rainfall regime involves less evaporation that will, in turn, reduce the number of multi-celled phytoliths. However, this is a problematic because the association between rainfall and evaporation rates is far more complex than they suggest. Moreover, the relative impacts of rainfall and evaporation on phytolith formation have not been established and cannot be assumed to balance each other out. Rosen and Weiner also argue that, unlike irrigation water, rain water is essentially silica free and hence will have little if any impact on phytolith formation. Whether or not this is the case, rain water will collect silica from the ground prior to being taken up by the plant. Unless the source of water that had been used by a plant can be established, one must rely on an independent measure of rainfall for 
the period and locality under study, such as by the isotopic analysis of lake sediments or calcite deposits. If this indicates a period of either stable or increasing aridity that coincides with high frequencies of multi-celled phytoliths in archaeological samples, one might then reasonably conclude that irrigation had been employed.

2. A second issue with the Rosen and Weiner's study concerns the impact of soil chemistry on phytolith formation. They were unable to explore this because they used a single locality and growing season for their experimental study. Previous research has shown, however, that the level of silica present in the soil will affect phytolith formation (Blackman 1968), while increased salinity levels will impede the uptake of silica in wheat (Nicolas et al. 1993). Although it will always be difficult to establish the precise chemistry of the soil within which cereals were grown in prehistory, an understanding of the relationship between soil chemistry and phytolith formation is critical if we are going to use phytolith size and structure as an indicator for irrigation.

3. A third issue with the Rosen and Weiner (1994) study derives from the small-scale nature of their experiment. They found that an additional $200 \mathrm{~mm}$ of water to the $224 \mathrm{~mm}$ of rain water resulted in a significant increase in multi-celled phytoliths. But would an additional $100 \mathrm{~mm}$ have had the same effect, or $50 \mathrm{~mm}$ ? It is unclear from their work whether the $200 \mathrm{~mm}$ had been established as the optimal additional amount to maximize yield prior to their experiment. Perhaps this was an excessive amount, unlikely to reflect the level of irrigation likely to be found in either prehistoric or historic times? A pertinent question is whether the size and number of multi-celled phytoliths increase in a linear fashion with enhanced irrigation levels or whether there is an exponential or another form of relationship? So, just as with the need to understand the impact of soil chemistry on phytolith formation, there is a need to establish the impact of varying levels of irrigation.

4. A final concern with the Rosen and Weiner (1994) study is with the potential impact of taphonomic processes on the presence and frequency of multi-celled phytoliths in archaeological samples. Although they noted that mechanical breakdown will select against the preservation of phytoliths with more than 100 cells, there has been no research (that we know of) on the breakdown of multi-celled phytoliths by aeolian, fluvial and other post-formation processes. So, even though single phytoliths are durable, the relative frequency of even 10-celled phytoliths may be primarily a reflection of taphonomic process rather than of the extent of past irrigation.

\section{The WLC experimental crop-growing programme}

The weaknesses we have pointed to in Rosen and Weiner's (1994) study are largely present because of the small-scale nature of their experimental work and because it was a truly pioneering study. Consequently we have devised an experimental crop-growing programme to build upon their research by exploring the relationship between soil chemistry, irrigation intensity and phytolith formation, which is then related to a 
programme of experiments concerning the impact of taphonomic processes on multi-celled phytolith preservation (that will be described elsewhere).

The 'Water, Life \& Civilisation' project's crop-growing experiments are conducted in Jordan in collaboration with NCARE (National Centre for Agricultural Research and Extension). We are assessing whether the proposed relationship between phytolith size and water availability holds true for three plant species: durum wheat ( $T$. durum), common barley (H. vulgare) and sorghum (Sorghum halapense). Initially it was intended to grow emmer wheat, which was an important early domesticate and would replicate the experiments of Rosen and Weiner (1994). Unfortunately, seeds of emmer wheat were not available at the time of planting, leading to the selection of durum wheat as a substitute (we are planning future experiments with emmer wheat). Barley was chosen because it was an important staple crop in the Near East and sorghum to explore whether a $\mathrm{C}_{4}$ grass would respond in the same way to the different levels of irrigation as the $\mathrm{C}_{3}$ grasses. At the time of planting, Sorghum halapense was the only sorghum available in Jordan.

During the first growing season (2005-6) these crops were grown under four irrigation regimes: no irrigation ( 0 per cent of the crop water requirements), sub-optimal irrigation (80 per cent of the crop water requirements), optimal irrigation (100 per cent of the crop water requirements) and over-optimal (120 per cent of the crop water requirements). These calculations were based on known crop water requirements estimated by using Class APan evaporation readings. A further condition ( 40 per cent of the crop water requirements) has been added for the second and on-going growing season (2006-7).

\section{Methodology}

\section{The set-up of the experimental plots}

Native land races of durum wheat (ACSAD 65) and common barley (ACSAD 176) were obtained from ACSAD (Arab Centre Studies Arid Zones and Dry Lands) and seeds of Sorghum halapense were collected from wild plants in Jordan. These are being grown at three different locations: Kherbet al-Samra, located to the northeast of Amman with an annual rainfall of $c$. $150 \mathrm{~mm}$; Ramtha, to the north of Amman, $5 \mathrm{~km}$ from the Syrian border, with c. 300-350mm rainfall per year; and Deir 'Alla in the Jordan valley, with $c$. $250 \mathrm{~mm}$ of rain per year (Fig. 1). Both Kherbet al-Samra and Ramtha are on the Jordanian plateau and are subject to greater temperature variation than Deir 'Alla which is in a more humid and continuously warm area. The use of three different locations is for the same reasons as in the wheat-growing experiments described by van der Veen (1989) in terms of establishing the impact of ecology and climate on both yield and phytolith formation.

Four plots are used for each species, one for each irrigation regime. Each plot measures $5 \mathrm{~m} \times 5 \mathrm{~m}$, is surrounded by a soil bund and has a $1.5 \mathrm{~m}$ separation from the adjacent plot. A drip irrigation system is used which has a $60 \mathrm{~cm}$ spacing between each line (i.e. water pipe) and a $40 \mathrm{~cm}$ spacing between the drippers on each pipe. Each irrigation plot has eight lines (Plate 1). Reclaimed waste water is used for irrigation at Kherbet al-Samra and Ramtha while mixed water is used at Deir 'Alla. The water was chemically, physically and biologically tested before the experiments began and was found to be within the Jordanian 


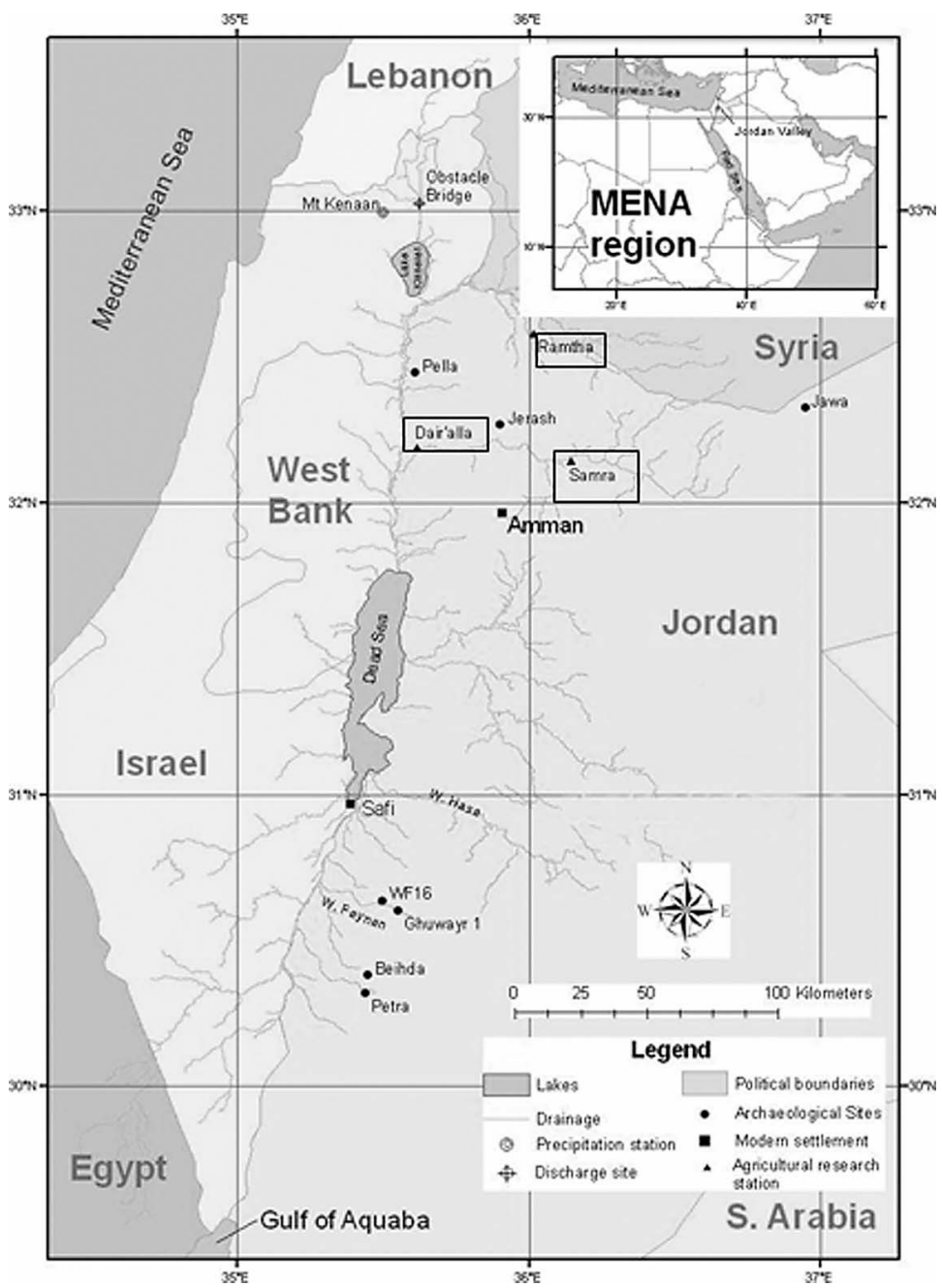

Figure 1 Map of the 'Water, Life \& Civilisation' study region showing location of crop growing stations.
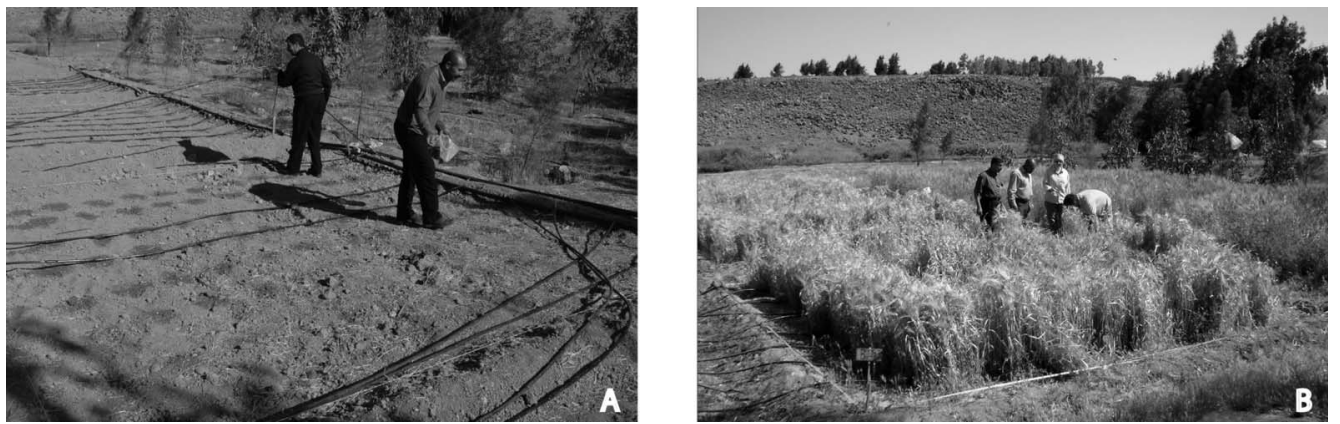

Plate 1 A: Planting; B: harvesting at Kherbet al Samra. 
standards for water use in crop irrigation. Meteorological data are available for all three stations which provide daily mean, maximum and minimum temperatures and the daily rainfall totals. Soil samples were taken from each plot before planting, which was characterized for a range of routine properties tested at $0-25 \mathrm{~cm}, 25-50 \mathrm{~cm}$ and $50-75 \mathrm{~cm}$ at NCARE. An additional test for silica will be conducted at the University of Reading.

\section{Planting and harvesting}

Initial sowing took place in November 2005, with the plots being ploughed prior to sowing, followed by regular monitoring of the crops on a weekly basis. Seeds were sown at a rate of $20 \mathrm{~kg} /$ dunam $\left(1\right.$ dunam $\left.=1000 \mathrm{~m}^{2}\right)$ for wheat and barley and $10 \mathrm{~kg} / \mathrm{d}$ for sorghum. The plots were monitored on a weekly basis for irrigation and weed control; no chemical weed killers, pesticides or fertilisers were employed. The wheat and barley were harvested when ripe in May 2006 and the sorghum in August 2006; Figure 2 illustrates the planting and harvesting at Kherbet al-Samra. Approximately twenty to thirty plants were sampled from each plot, using a diagonal $50 \mathrm{~cm}$ grid system to get a representative sample of the whole plot. In addition to the plants taken for phytolith analysis, a $1 \mathrm{~m} \times 1 \mathrm{~m}$ square was sampled for total fresh yield, grain yield and straw yield, and one plant was taken from each plot for chemical analysis. These plants were oven dried and crushed and tested for total N (nitrogen), P (phosphorus) and K (potassium) at NCARE. A soil sample was also taken after harvesting. Each plot is fully harvested, weeded and tilled before re-sowing.

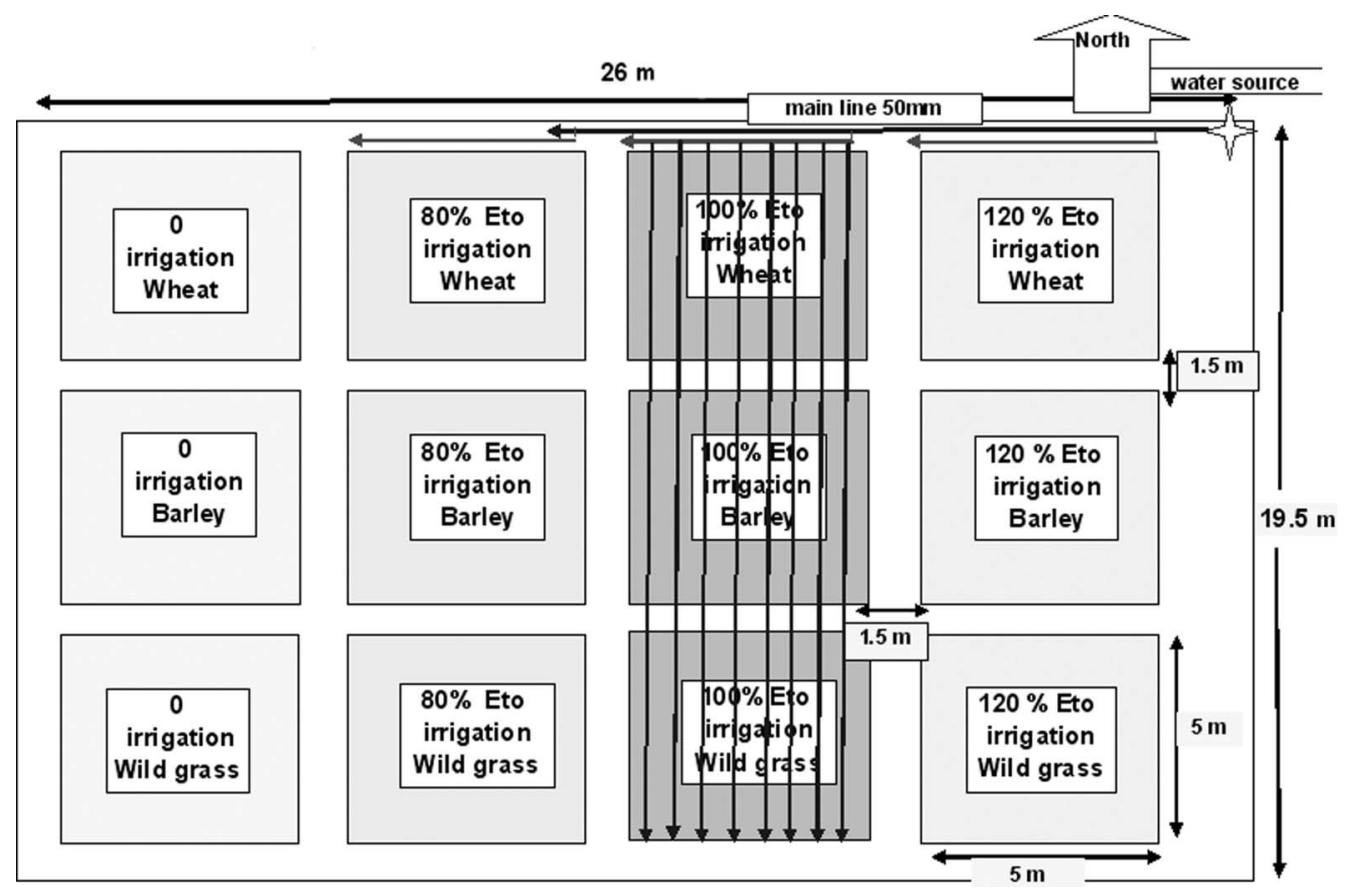

Figure 2 Crop-growing layout for Kherbet al Samra. 


\section{Laboratory work}

The first crop to be analysed for phytoliths was the wheat from Kherbet al-Samra. Initially ten plants were taken from the optimal irrigation plot. These were washed in distilled water and then cut up according to plant part (awn, husk, leaf and stem) and placed in a weighed crucible. The crucibles were then re-weighed after the plant material had been added. These were then placed in a muffle furnace and burnt for two and a half hours. The awns and husks were burnt at $500^{\circ} \mathrm{C}$, while the leaves and stems had to be burnt at $600^{\circ} \mathrm{C}$ to ash them completely. The crucibles were re-weighed after ashing so that the weight of the phytolith could be determined. Five plants were ashed and the residues mounted directly onto microscope slides while the other five were rinsed in 10 per cent hydrochloric acid before mounting. The results showed that the subsequent rinse in 10 per cent HCL did not increase the quality of the slides produced but did lower the phytolith yield. Therefore a decision was made to process the samples without a subsequent rinse in 10 per cent HCL to maximize the samples produced. In total, twenty plants were sampled from each of the irrigation plots at Kherbet al-Samra and processed, by plant part, for phytoliths.

\section{Results}

\section{Success of crop growth}

Differences in crop growth were seen not only between the different irrigation regimes but also between the same crops at different research stations. For wheat and barley Kherbet al-Samra was the most successful station. The plants in the optimally irrigated plots grew best, followed by the sub-optimal and over-optimal and lastly the un-irrigated plots. However, this was not the case for sorghum. While the sorghum was present in the underoptimal, optimal and over-optimal plots it did not grow at all in the un-irrigated plot at Kherbet al-Samra.

Bird attack was a problem at both Ramtha and Deir 'Alla and mesh had to be suspended over the plots, leading to an increase in humidity and weed growth (a problem also experienced by other experimental crop-growing programmes, e.g. van der Veen 1989). At Ramtha the un-irrigated plots of wheat and barley matured before the other plots and suffered the worst attack by birds. In addition, the un-irrigated wheat and barley were affected by rust, especially the plants in the middle of the plots. This may be because the plants were unaccustomed to the increased humidity caused by netting, while the irrigated plants were more accustomed to receiving water. Overall the un-irrigated plots of wheat and barley fared better at Ramtha than at Kherbet alSamra. In addition, the un-irrigated sorghum did grow, albeit poorly, at Ramtha. The over-optimally irrigated sorghum was the most successful plot, while optimally irrigated and under-optimally irrigated looked similar in growth.

Deir 'Alla was the most problematic of the three crop-growing stations. Bird attack was ferocious and the majority of the plots were infested with weeds. Both the wheat and barley matured at the same time even though the growing season is usually shorter 
for barley. The over-optimal and optimally irrigated wheat and barley plots were badly contaminated by weeds; these comprised approximately three-quarters of the plots. In the under-optimal plots approximately half of the area consisted of weeds. Interestingly, the un-irrigated plots grew most successfully and were not as badly contaminated by weeds. Sorghum grew in all of the plots at Deir 'Alla, even the unirrigated plot. The plants grew most successfully at the plot edges for all of the crops at Deir 'Alla.

\section{Crop yield}

A $1 \mathrm{~m} \times 1 \mathrm{~m}$ area was sampled for yield from each of the irrigation plots. This was analysed at NCARE and expressed as tonnes per hectare. Yield was calculated for total fresh yield (Total Fresh Yield), which was then broken down into grain yield (GY) and straw yield (SY). Figure 3 shows the results for the wheat and barley from the 2005 and 2006 growing seasons.

\section{Barley yield}

The greatest total fresh yield for the un-irrigated barley came from Ramtha while Kherbet al Samra had a low yield from the un-irrigated plot which produced no grains at all. Grain yield for the un-irrigated plot was also low at Deir'Alla with most of the total fresh yield consisting of straw. Irrigation resulted in a discernible increase in crop yield at Kherbet al Samra with optimal irrigation raising total fresh yield fivefold.

Results of rainfall calculations show that there was less rain during the barley-growing season at Kherbet al Samra than at Ramtha and Deir 'Alla; while Kherbet al Samra had a total rainfall of $77.2 \mathrm{~mm}$, Ramtha received $119.3 \mathrm{~mm}$ and Deir 'Alla $201.2 \mathrm{~mm}$ of rain during the growing season which would have greatly affected this result. In addition, the evapo-transpiration rate was higher at Kherbet al Samra than at Ramtha and Deir 'Alla. The amount of rain that fell in the Jordan Valley during the 2005 to 2006 growing season was greater than in average years, demonstrating the importance of replicating the experiments. The yield results from Ramtha show that there is a steady increase in total fresh yield, grain yield and straw yield as the irrigation levels increase, with the greatest total fresh yield for all sites coming from the over-optimally irrigated plot with 19.4 tons per hectare. At Deir 'Alla the optimally and over-optimally irrigated plots performed similarly for all types of yield.

\section{Wheat yield}

Once again the yield for the un-irrigated plot was lowest at Kherbet al Samra with no grains being collected from this plot. Yield was low at Ramtha, though grains were present in the un-irrigated plants. However, while the un-irrigated barley yield was greatest at Ramtha, the un-irrigated wheat yield was highest for Deir 'Alla with 6.5 tons per hectare. The greatest overall total fresh yield came from the optimally irrigated plot at Kherbet al Samra but this plot did not have the highest grain yield, which was found in the optimally 


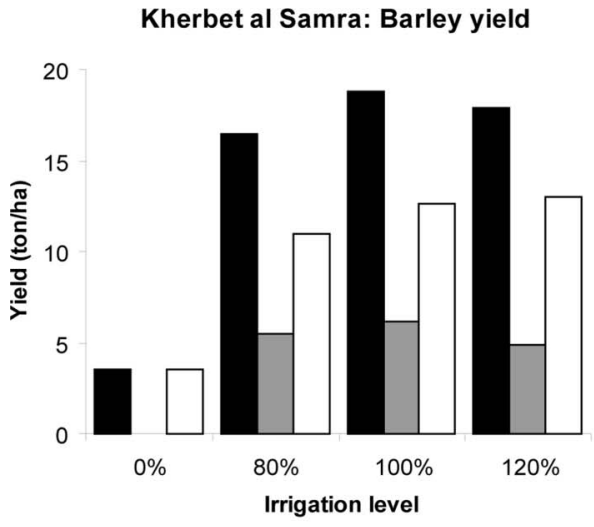

Ramtha: Barley yield

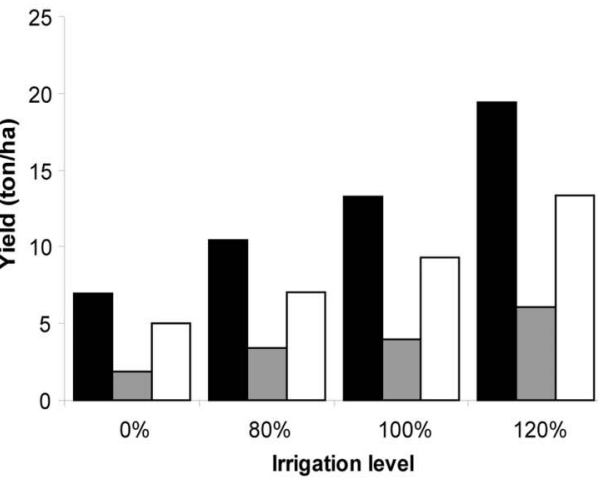

Deir 'Alla: Barley yield

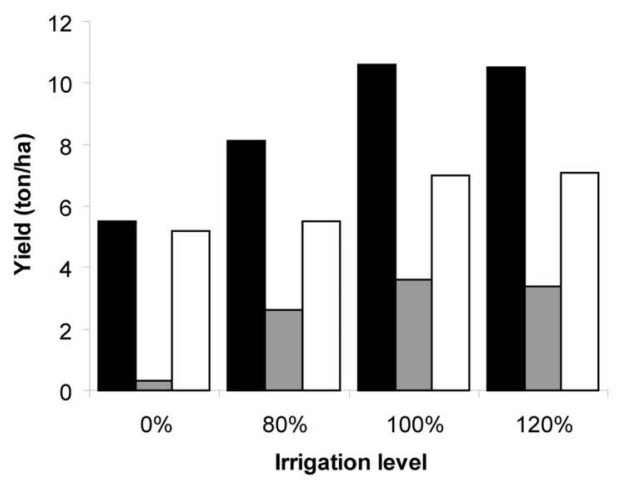

Kherbet al Samra: Wheat yield

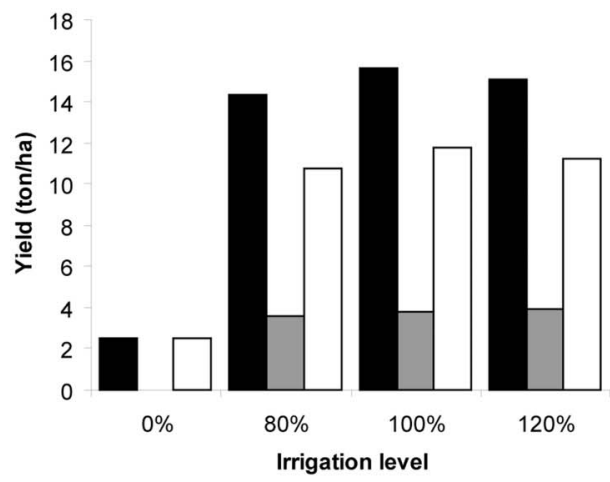

Ramtha: Wheat yield

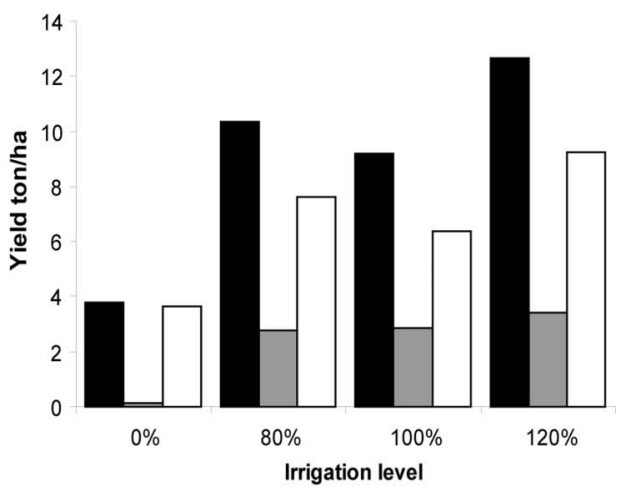

Deir 'Alla: Wheat yield

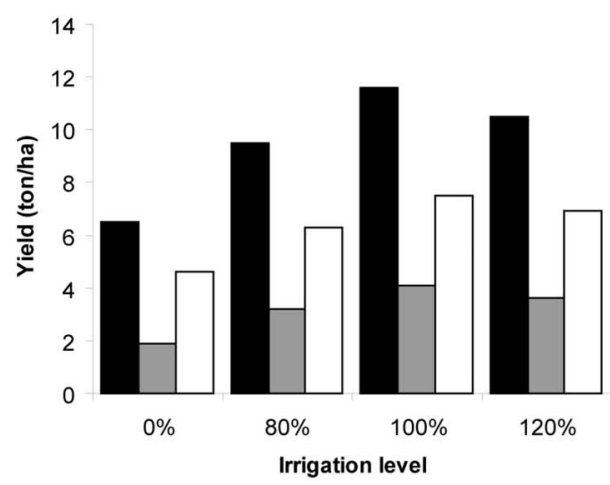

- Total Fresh Yield $\square$ Grain Yield $\square$ Straw Yield

Figure 3 Total fresh yield, grain yield and straw yield for the wheat and barley for all sites from the 2005-6 growing season.

irrigated plot at Deir 'Alla. Grain production was similar for all the irrigated plots at Kherbet al Samra, while the optimally irrigated plot had the most grain at Deir 'Alla and the over-optimally irrigated plot the greatest grain yield at Ramtha. 


\section{Phytolith yield}

Phytolith yield is the amount of phytoliths produced from a known amount of plant matter. This is a useful calculation for establishing phytolith production in a modern growing situation but is, of course, redundant in archaeological contexts when the amount of original plant matter is unknown. As this work is ongoing the results presented here are based only on the wheat from Kherbet al Samra and Deir 'Alla, from the 2005-6 growing season. Figure 4 shows the weight percentage of the phytoliths from the wheat grown at Kherbet al Samra. This illustrates that there is a steady increase in the weight percentage of phytoliths as the level of irrigation increases. However, when this is broken down into plant part (awn, husk, leaf and stem) the results are less straightforward. While the husks and the stems show an increase in weight percentage as the irrigation level rises, the awns and the stems show a less uniform response to the various irrigation regimes. The stems were difficult to ash completely and so this sporadic result could partly be a reflection of residual charcoal in some of the samples which affected the weight percentage but no such problem was encountered with the awns. Partly as a response to this result and partly due to the difficulty in counting the conjoined cells from the awns, leaves and stems, a decision was taken to analyse only the husks for the rest of the modern crops.

Figure 5 shows a comparison of the weight percentage of the phytoliths from the wheat from Kherbet al Samra and Deir 'Alla; these results are based on a sample of twenty

$\square$ awn $\square$ husk $\square$ leaf $\mathbf{\square}$ stem

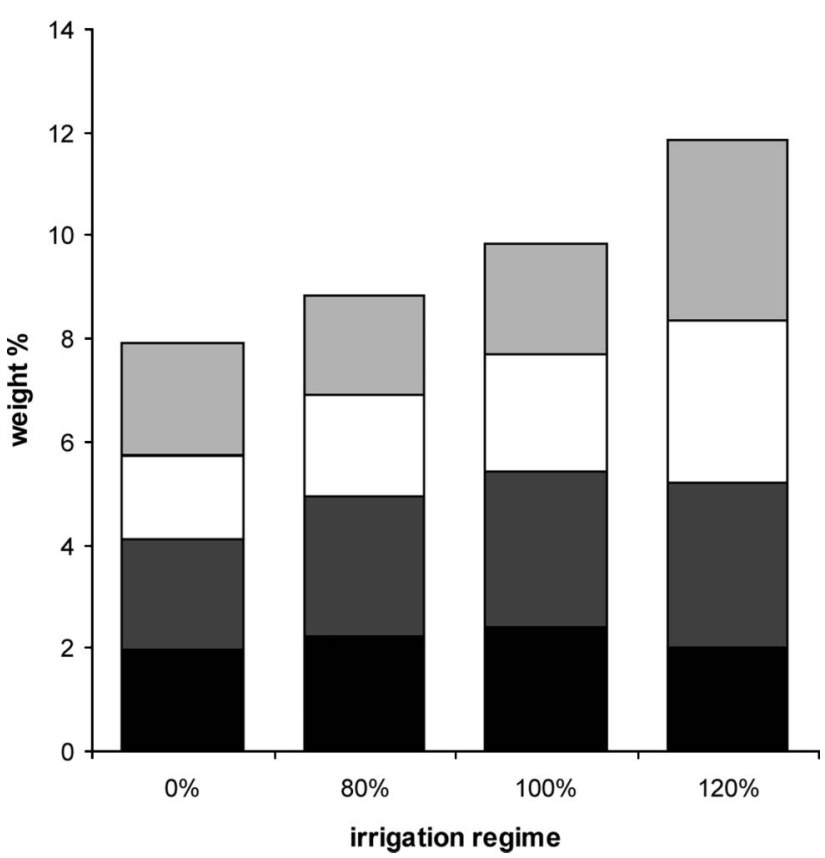

Figure 4 Phytolith yield by plant part for the wheat from Kherbet al Samra. 
Kherbet as Samra $\square$ Deir 'Alla

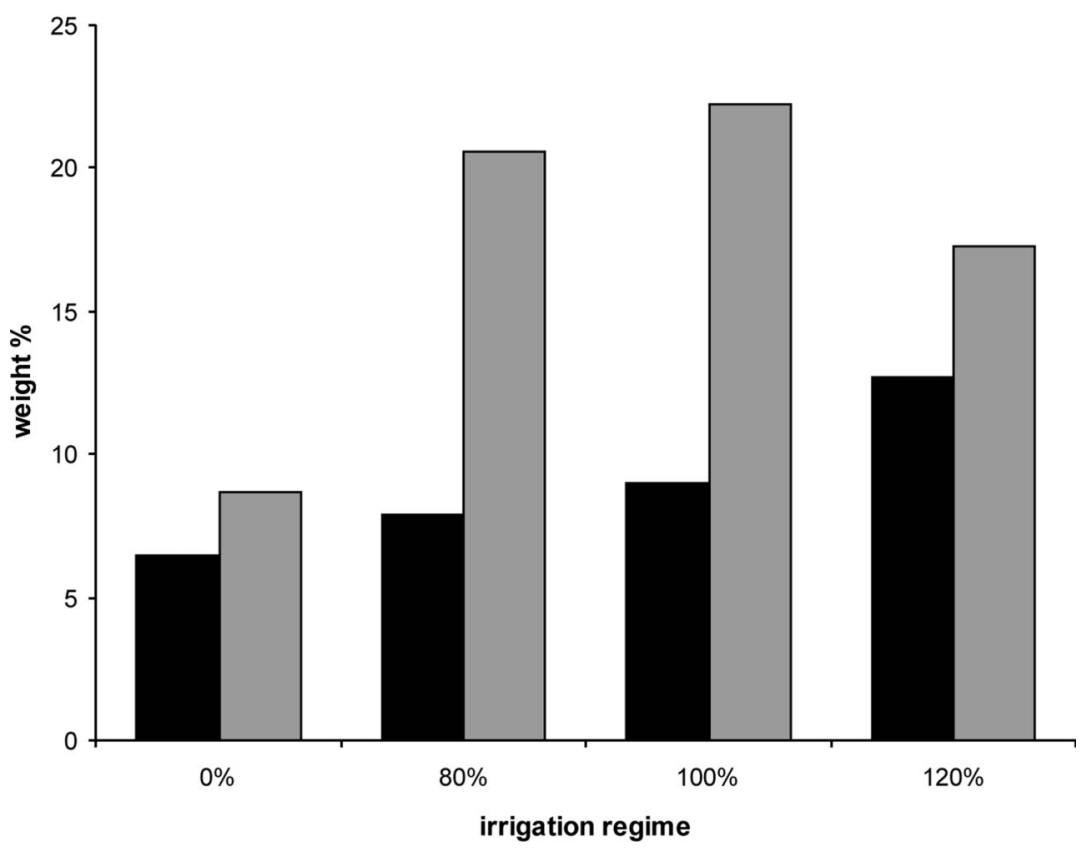

Figure 5 Comparison of the weight percentages of husk phytoliths from Kherbet al Samra and Deir 'Alla.

plants. From this it is apparent that the wheat husks from Deir 'Alla produced a greater percentage of phytoliths than those from Kherbet al Samra, with the under-optimally irrigated and optimally irrigated wheat husks from Deir 'Alla having over twice the weight percentage of those from Kherbet al Samra. The phytolith weight percentages of husks from Deir 'Alla are also greater than those of Rosen and Weiner (1994). The husks from the irrigated emmer wheat grown in Gilat had a mean weight percentage of 3.86 while the un-irrigated samples had a weight percentage of 2.09. This is considerably less than was obtained from the optimally irrigated wheat husks from Deir 'Alla which had a weight percentage of 22.2. However, Rosen and Weiner's (1994) results for the weight percentage of husks from the durum wheat from irrigated fields at Beit Qama, Israel, is much higher at 13.71 percentage. This is interesting as it may suggest that durum wheat is a more prolific producer of phytoliths than emmer wheat.

\section{Phytolith form}

The phytoliths found in the wheat samples from Kherbet al Samra have yet to be quantified but some differences were discernible from initial observations. The un-irrigated plot ( 0 per cent irrigation) produced large but poorly silicified phytoliths, making it difficult to distinguish and identify the individual phytolith forms in the multi-cells, as 
illustrated in Plate 2. The under-optimal plot (80 per cent irrigation) produced some large multi-celled phytoliths but these were not as large as those found in the 100 per cent irrigated plots. The optimally irrigated plot (100 per cent irrigation) produced very large conjoined multi-celled phytoliths which could be described as 'phytolith sheets'. These consisted of many hundreds of cells conjoined to make one enormous multi-celled phytolith. Finally the over-optimal plot (120 per cent irrigation) produced many multicelled phytoliths which were similar to the ones observed in the under-optimal irrigation plot but there were also some multi-celled phytoliths that were poorly silicified and similar to those found in the un-irrigated samples.

\section{Discussion}

The results obtained from the crop yield calculations demonstrate that, as one might expect, crop yield increases with irrigation. In the majority of plots the greatest crop yield was obtained from the optimally irrigated plot. However, at both Ramtha and Deir 'Alla, which had a total rainfall over the growing season of $119.3 \mathrm{~mm}$ and $201.2 \mathrm{~mm}$ respectively, rainfall alone was sufficient to produce grain for both wheat and barley. This is pertinent
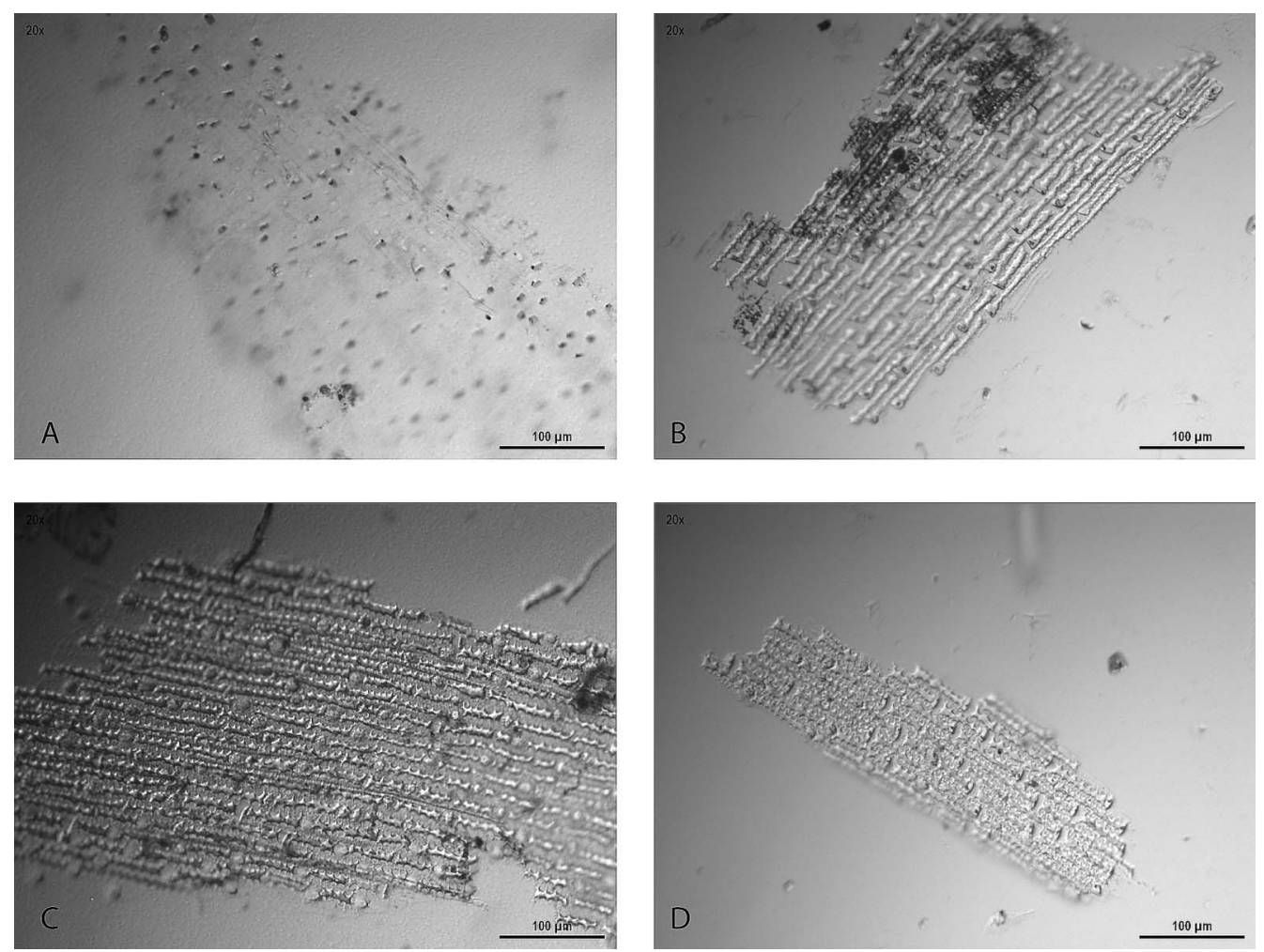

Plate 2 Images of the multi-celled phytoliths produced by the wheat plants grown at Kherbet al Samra. A: no irrigation, B: sub-optimal irrigation, C: optimal irrigation, D: over-optimal irrigation. 
because the recommended level of irrigation for barley is $200-50 \mathrm{~mm}$ and for wheat is 250 $300 \mathrm{~mm}$. The results from the analysis of the phytolith yield are more challenging to interpret due to the variety of factors that can influence silica uptake and phytolith production. Differences in evapo-transpiration rates could be the main cause of this variation in phytolith yields. Class A Pan-evaporation readings were taken from all three sites and were used to calculate crop water requirements. These figures demonstrate that the evaporation rate was greatest at Kherbet al Samra during the growing season for both barley and wheat.

At Deir "Alla an interesting phenomenon occurred with the growth period for wheat being shorter than usual. At this site the wheat matured at the same time as the barley despite the growing season for barley being shorter than for wheat. This accelerated growth may be due to the increased heat and humidity caused by covering the plot in mesh to protect the plants from birds. In total, the evaporation rate was $397.5 \mathrm{~mm}$ for Kherbet al Samra for the barley-growing season and $500.6 \mathrm{~mm}$ for the wheat-growing season, in contrast to $378.5 \mathrm{~mm}$ for Deir 'Alla. This increased level of evaporation, leading to an increase in evapo-transpiration in the plants, could have resulted in accelerated silica uptake through the groundwater.

Another critical factor for phytolith production is the amount of available silica ( $\mathrm{Si}$ ) in the growing medium. It has been demonstrated that phytolith production is proportional to the amount of $\mathrm{Si}$ in the growing medium for oats and rice (Jones and Milne 1963; Okuda and Takahashi 1964). In addition, aluminium oxides and to a lesser extent iron oxides can be absorbers of silica, meaning that there is less available in the transpiration stream (McKeague and Cline 1963). Soils analysis to assess the levels of silica and for aluminium and iron oxides is currently being undertaken at the Department of Soil Science, University of Reading, and it will be interesting to observe if differences in the levels of these could have attributed to the greater phytoliths yield at Deir 'Alla compared to Kherbet al Samra. As noted above, increased salinity levels are known to reduce transpiration rates in $T$. aestivum and $T$. durum, which could in turn affect phytolith production (Nicolas et al. 1993). Deir 'Alla has a lower level of soil salinity than Kherbet al Samra, which may have contributed to the lower weight percentage of phytoliths from the husks from this site.

The general health of the plant may also be a variable that affects silica uptake. It has been observed that silica precipitation may be a response to fungal attack in some plant species. This has been observed for the French bean (Phaseolus vulgaris) where it was noted that silica deposition occurred in the mesophyll cell walls in the same areas of the leaf that had been affected by cow pea rust (Uromyces phaseoli/vignae) (Heath 1979). As noted above, the plants from Deir 'Alla suffered from rust and, if the increase in silica precipitation in response to rust holds true for all plant species, this may also have contributed to the higher weight percentage of phytoliths in the plants from Deir 'Alla.

\section{Conclusions}

Phytolith analysis is becoming widespread in archaeology and so it is vital to understand the factors that influence the size, shape, structure and preservation of phytoliths in the 
archaeological record. Unravelling the relative influence of plant species, plant part, plant health, soil chemistry and evapo-transpiration on the formation of phytoliths is challenging and will take at least three years of crop-growing experiments to construct a sufficiently large body of data. In addition, further experiments are necessary (and are currently being devised) to address issues of phytolith taphonomy. By undertaking such programmes of experimentation, it may be possible to provide a new method for the inference of ancient crop irrigation, one to be used in conjunction with other potential indicators such as grain size, weed floras and structural evidence.

The initial results from our experiments are positive: irrigation does appear to have a significant effect on phytolith size and structure, supporting the claims of Rosen and Weiner (1994). But we have yet to complete the quantitative analysis of the phytoliths from the first year of experimental crop growing and (at date of writing, May 2007) are just about to harvest the crops from the second year. For this second year of the experiment we have included a plot with 40 per cent of the optimal irrigation. This recognizes that the results from the first year are insufficient to indicate whether the increases in, for example, barley yields from Kherbet al Samra and in husk phytoliths from Deir 'Alla, from the 0 per cent to 80 per cent irrigation levels should be considered as a gradual increase or whether there is some other form of relationship.

We are aware that there are potentially numerous additional factors that are likely to influence both yields and phytolith formation that we are unable to consider within our experimental design. As with any research project we are ultimately limited by resource availability and the crop-growing experiments we have described need constant attention to ensure irrigation levels are correctly applied, along with substantial laboratory studies for the phytolithic and chemical analysis. The potential long-term benefits are substantial. If these experiments can demonstrate a significant and consistent relationship between phytolith formation and irrigation, and if we can develop an understanding of phytolith taphonomy and control for overall changes in precipitation, then we should be able to make direct inferences regarding irrigation at Neolithic, Chalcolithic and Bronze Age sites in the Jordan Valley. By so doing, we hope to make a significant contribution to our understanding of the relationship between water management and the evolution of social complexity.

\section{Acknowledgement}

We are grateful to the Leverhulme Trust for funding the 'Water, Life \& Civilisation' project (grant F/00239/R).

Steven Mithen

School of Human \& Environmental Sciences, University of Reading, UK

Emma Jenkins

School of Human \& Environmental Sciences, University of Reading, UK

Khalil Jamjoum

National Centre for Agricultural Research and Extension, Amman, Jordan

Sameeh Nuimat

Ministry of Agriculture, Land and Irrigation Department, Amman, Jordan 
Stephen Nortcliff School of Human \& Environmental Sciences, University of Reading, UK Bill Finlayson Council for British Research in the Levant, Amman, Jordan

\section{References}

Anderson, P. S. 1992. Prehistoire de L'agriculture. Paris: CNRS Press.

Barker, G. 2000. Farmers, herders and miners in the Wadi Faynan, southern Jordan: a 10,000-year landscape archaeology. In The Archaeology of Drylands (eds G. Barker and D. Gilbertson). London: Routledge, pp. 63-85.

Bellwald, U. and al-Huneidi, M. 2003. The Petra Siq: Nabataean Hydrology Uncovered. Amman: Petra National Trust.

Blackman, E. 1968. The pattern and sequence of opaline silica deposition in rye (Secale cereale L.). Annals of Botany, 32: 207-18.

Bourke, S. J. 2001. The Chalcolithic period. In The Archaeology of Jordan (eds B. MacDonald, R. Adams and P. Bienkowski). Sheffield: Sheffield Academic Press, pp. 109-62.

Charles, M., Hoppé, C., Jones, G., Bogaard, A. and Hodgson, J. G. 2003. Using weed functional attributes for the identification of irrigation regimes in Jordan. Journal of Archaeological Science, 30: $1429-41$.

Davies, M. S. and Hillman, G. C. 1988. Effects of soil flooding on growth and grain yield of populations of tetraploid and hexaploid species of wheat. Annals of Botany, 62: 597-604.

Galili, E., Rosen, B., Gopher, A. and Horwitz, L. K. 2002. The emergence and dispersion of the eastern Mediterranean fishing village: evidence from submerged Neolithic settlements of the Carmel coast. Journal of Mediterranean Archaeology, 15: 167-98.

Garfinkel, Y., Vered, A. and Bar-Yosef, O. 2006. The domestication of water: the Neolithic well at Shar'ar Hagolan, Jordan Valley, Israel. Antiquity, 80: 686-96.

Heath, M. C. 1979. Partial characterisation of the electron-opaque deposits formed in the nonhost plant, French bean, after cow pea rust infection. Physiological Plant Pathology, 15: 141-8.

Helbaek, H. 1960. Ecological effects of irrigation in ancient Mesopotamia. Iraq, 22: 186-96.

Helms, S. W. 1981. Jawa: Lost City of the Black Desert. New York: Cornell University Press.

Helms, S. W. 1989. Jawa at the beginning of the Middle Bronze Age. Levant, 21: 141-68.

Hillman, G. C. and Davies, M. S. 1990. Domestication rates in wild-type wheats and barley under primitive cultivation. Biological Journal of the Linnean Society of London, 39: 39-78.

Jones, L. H. P. and Milne, A. A. 1963. Studies of silica in the oat plant I. Chemical and physical properties of the silica. Plant and Soil, 18: 207-20.

Kuijt, I., Finlayson, B. and MacKay, J. 2007. Pottery Neolithic landscape modification at Dhra'. Antiquity, 81: 106-18.

Lie-Dan Lu, T. 2002. A green foxtail (Setaria viridis) cultivation experiment in the Middle Yellow River Valley and some related issues. Asian Perspectives, 41: 1-13.

Mabry, J., Donaldson, M. L., Gruspier, K., Mullen, G., Palumbo, G., Rawlings, M. N. and Woodburn, M. A. 1996. Early town development and water management in the Jordan Valley: investigations at Tell el-Handaquq North. Annual of the American Schools of Oriental Research, 53: $115-54$.

McKeague, J. A. and Cline, M. G. 1963. Silica in soil solutions II: the adsorption of monosilicic acid by soil and by other substances. Canadian Journal of Soil Science, 43: 83-96. 
Nicolas, M. E., Munns, R., Samarakoon, A. B. and Gifford, R. M. 1993. Elevated $\mathrm{CO}_{2}$ improves the growth of wheat under salinity. Australian Journal of Plant Physiology, 20: 349-60.

Oka, H. and Morishima, H. 1971. The dynamics of plant domestication: cultivation experiments with Oryza perennis and its hybrid Oryza sativa. Genetics, 78: 475-86.

Okuda, A. and Takahashi, E. 1964. The role of silicon. In The Mineral Nutrition of the Rice Plant. Proceedings of the Symposium of the International Rice Research Institute. Baltimore, MD: Johns Hopkins University Press, pp. 123-46.

Oleson, J. P. 2001. Water supply in Jordan through the ages. In The Archaeology of Jordan (eds B. MacDonald, R. Adams and P. Bienkowski). Sheffield: Sheffield Academic Press, pp. 603-24.

Peltenburg, E., Colledge, S., Croft, P., Jackson, A., McCartney, C. and Murray, M. A. 2000. Agropastoralist colonisation of Cyprus in the 10th millennium BP: initial assessment. Antiquity, 74: $844-53$.

Philip, G. 2001. The Early Bronze I-III Ages. In The Archaeology of Jordan (eds B. MacDonald, R. Adams and P. Bienkowski). Sheffield: Sheffield Academic Press, pp. 163-212.

Rosen, A. M. and Weiner, S. 1994. Identifying ancient irrigation: a new method using opaline phytoliths from emmer wheat. Journal of Archaeological Science, 21: 125-32.

Scarborough, V. L. 2003. The Flow of Power: Ancient Water Systems and Landscapes. A School of American Research Resident Scholar Book. Santa Fe, NM: SAR Press.

Van der Veen, M. 1989. National wheat-growing experiment: interim report 1987/8. Circaea, 6: 71-6. Van der Veen, M. and Palmer, C. 1997. Environmental factors and the yield potential of ancient wheat crops. Journal of Archaeological Science, 24: 163-82.

Whitehead, P. G., Smith, S. J., Wade, A. J., Mithen, S. J., Finlayson, B. L., Sellwood, B. and Valdes, P. in press. Modelling of hydrology and potential population levels at Bronze Age Jawa, northern Jordan: a Monte Carlo approach to coping with uncertainty. Journal of Archaeological Science.

Wittfogel, K. A. 1957. Oriental Despotism: A Comparative Study of Total Power. New Haven, CT: Yale University Press.

Steven Mithen is Professor of Early Prehistory and Head of the School of Human \& Environmental Sciences at the University of Reading. He is the lead PI of the 'Water, Life \& Civilisation' project, and co-directs excavations at the Neolithic site of WF16 in Wadi Faynan, Southern Jordan (with Bill Finlayson). He also directs survey and excavation regarding Mesolithic settlement in Western Scotland, most recently on the Islands of Tiree, Coll and Mull. His books include After the Ice (2003), The Singing Neanderthals (2005) and the edited monograph (with Bill Finlayson) The Early Prehistory of Wadi Faynan (2007).

Emma Jenkins is a post-doctoral research fellow working on the 'Water, Life \& Civilisation' project at the University of Reading. She originally started her academic career as a microfauna specialist and received her $\mathrm{PhD}$ from Cambridge University in 2004. She then began working on phytoliths with Dr Arlene Rosen as a post-doctoral research fellow at the Institute of Archaeology, UCL. Her research interests are focused on the development of agriculture and sedentism in the Near East. 
Khalil Jamjoum is a main researcher in National Centre for Agricultural Research and Extension(NCARE)/Jordan in the field of reuse of treated waste water in agriculture. In 1987 he gained his MSc degree in soil and irrigation from the Faculty of Graduate Studies, University of Jordan. His interests are focused on the reuse of low quality water (marginal water, saline and reclaimed water) for the irrigation of restricted agricultural crops.

Sameeh Al Nuimat has a degree in agricultural science from the University of Jordan and is currently studying for an MSc at Jordan University for Science and Technology. He has recently been involved in projects concerned with monitoring farming activity within the Zarqa River basin and testing the response of Eucalyptus, and casuarinas Sp. to irrigation by treated waste water.

Stephen Nortcliff is Professor of Soil Science at the University of Reading and one of the PIs on the 'Water, Life \& Civilisation' project. He has worked in a wide range of environments focusing on sustainable soil management practices and the impacts of land use change on resource use. His current work in Jordan focuses on the potential use of recycled water to supplement the exceptionally scarce fresh water supplies.

Bill Finlayson is Director of the Council for British Research in the Levant and a Visiting Professor at the University of Reading with broad interests in Late Pleistocene and early Holocene hunter-gatherers. He co-directs excavations at the Neolithic site of WF16 in Wadi Faynan, Southern Jordan (with Mithen) and at the Neolithic site of Dhra (with Kuijt). Bill also directs research concerning experimental archaeology, conservation and site presentation at Beidha. He is a co-editor of the monograph The Early Prehistory of Wadi Faynan (2007). 